\title{
Erwin Schrödinger and Quantum Wave Mechanics
}

\author{
John J. O'Connor \& Edmund F. Robertson \\ School of Mathematics and Statistics, University of St Andrews, North Haugh, St Andrews, Fife, Scotland \\ E-mails:joc@st-andrews.ac.uk, efr@st-andrews.ac.uk \\ Editors: Stefan K. Kolev \& Danko Georgiev
}

Article history: Submitted on August 9, 2017; Accepted on August 20, 2017; Published on August 22, 2017.

\begin{abstract}
he fathers of matrix quantum mechanics believed that the quantum particles are unanschaulich (unvisualizable) and that quantum particles pop into existence only when we measure them. Challenging the orthodoxy, in 1926 Erwin Schrödinger developed his wave equation that describes the quantum particles as a packet of quantum probability amplitudes evolving in space and time. Thus, Schrödinger visualized the unvisualizable and lifted the veil that has been obscuring the wonders of the quantum world.
\end{abstract}

Quanta 2017; 6: 48-52.

Erwin Schrödinger's father, Rudolf Schrödinger, ran a small linoleum factory which he had inherited from his own father. Erwin's mother, Emily Bauer, was half English, this side of the family coming from Leamington Spa, and half Austrian with her father coming from Vienna.

Schrödinger learnt English and German almost at the same time due to the fact that both were spoken in the household. He was not sent to elementary school, but received lessons at home from a private tutor up to the age of ten. He then entered the Akademisches Gymnasium in the autumn of 1898, rather later than was usual since he spent a long holiday in England around the time he might have entered the school. He wrote later about his time at

(c) $(9)$ This is an open access article distributed under the terms of the Creative Commons Attribution License CC-BY-3.0, which permits unrestricted use, distribution, and reproduction in any medium, provided the original author and source are credited. the Gymnasium:

I was a good student in all subjects, loved mathematics and physics, but also the strict logic of the ancient grammars, hated only the memorization of incidental dates and facts. Of the German poets, I loved especially the dramatists, but hated the pedantic dissection of their works. [1, §1]

A student in Schrödinger's class at school also wrote:

Especially in physics and mathematics, Schrödinger had a gift for understanding that allowed him, without any homework, immediately and directly to comprehend all the material during the class hours and to apply it. After the lecture [...] it was possible for [our professor] to call Schrödinger immediately to the blackboard and to set him problems, which he solved with playful facility. For us average students, mathematics and physics were frightful subjects, but they were his preferred fields of knowledge. [1, §1]

Schrödinger graduated from the Akademisches Gymnasium in 1906 and, in that year, entered the University of Vienna. In theoretical physics, he studied analytical mechanics, applications of partial differential equations to dynamics, eigenvalue problems, Maxwell's equations and electromagnetic theory, optics, thermodynamics, and statistical mechanics. It was Fritz Hasenöhrl's lectures on theoretical physics which had the greatest influence on Schrödinger. In mathematics, he was taught calculus 
and algebra by Franz Mertens, function theory, differential equations and mathematical statistics by Wilhelm Wirtinger (whom he found uninspiring as a lecturer). He also studied projective geometry, algebraic curves and continuous groups in lectures given by Gustav Kohn.

On May 20, 1910, Schrödinger was awarded his doctorate for the dissertation On the Conduction of Electricity on the Surface of Insulators in Moist Air [2]. After this he undertook voluntary military service in the fortress artillery. Then he was appointed to an assistantship at Vienna but, rather surprisingly, in experimental physics rather than theoretical physics. He later said that his experiences conducting experiments proved an invaluable asset to his theoretical work since it gave him a practical philosophical framework in which to set his theoretical ideas.

Having completed the work for his habilitation, he was awarded the degree on September 1, 1914. That it was not an outstanding piece of work is shown by the fact that the committee was not unanimous in recommending him for the degree. As Walter J. Moore writes:

Schrödinger's early scientific development was inhibited by the absence of a group of first-class theoreticians in Vienna, against whom he could sharpen his skills by daily argument and mutual criticism. [1, §2]

In 1914, Schrödinger's first important paper was published developing ideas of Boltzmann. However, with the outbreak of World War I, Schrödinger received orders to take up duty on the Italian border. His time of active service was not wasted as far as research was concerned, however, for he continued his theoretical work, submitting another paper from his position on the Italian front. In 1915, he was transferred to duty in Hungary and from there he submitted further papers for publication. After being sent back to the Italian front, Schrödinger received a citation for outstanding service commanding a battery during a battle.

In the spring of 1917, Schrödinger was sent back to Vienna and assigned to teach a course in meteorology. He was able to continue research and it was at this time that he published his first results on quantum theory. After the end of the war he continued working at Vienna. From 1918 to 1920 , he made substantial contributions to the theory of colour vision [3-77].

Schrödinger had worked at Vienna on radioactivity, proving the statistical nature of radioactive decay. He had also made important contributions to the kinetic theory of solids, studying the dynamics of crystal lattices. On the strength of his work he was offered an associate professorship at Vienna in January 1920 but by this time he wished to marry Anny Bertel. They had become engaged in 1919 and Anny had come to work as a secretary in Vienna on a monthly salary which was more than Schrödinger's annual income. Then he was offered an associate professorship, still not at a salary large enough to support a non-working wife, so he declined.

Schrödinger accepted instead an assistantship in Jena and this allowed him to marry Anny on March 24, 1920. After only a short time there, he moved to a chair in Stuttgart where he became friendly with Hans Reichenbach. He then moved to a chair at Breslau, his third move in eighteen months. Soon however he was to move yet again, accepting the chair of theoretical physics in Zürich in late 1921. During these years of changing from one place to another, Schrödinger studied physiological optics, in particular he continued his work on the theory of colour vision [8--12].

Hermann Weyl was Schrödinger's closest colleague in his first years in Zürich and he was to provide the deep mathematical knowledge which would prove so helpful to Schrödinger in his work. The intellectual atmosphere in Zürich suited Schrödinger and Zürich was to be the place where he made his most important contributions. From 1921 he studied atomic structure, then in 1924 he began to study quantum statistics. Soon after this he read de Broglie's thesis which became a turning point in the direction of his research and had a major influence on his thinking. On November 3, 1925 Schrödinger wrote to Albert Einstein:
A few days ago I read with great interest the ingenious thesis of Louis de Broglie, which I finally got hold of $[\ldots][1, \S 6]$

On November 16, in another letter to Alfred Landé, professor of physics at Tübingen, Schrödinger wrote:

I have been intensely concerned these days with Louis de Broglie's ingenious theory. It is extraordinarily exciting, but still has some very grave difficulties. [1, §6]

One week later Schrödinger gave a seminar on de Broglie's work and a member of the audience, a student of Sommerfeld's, suggested that there should be a wave equation. Within a few weeks Schrödinger had found his wave equation.

Schrödinger published his revolutionary work relating to wave mechanics and the general theory of relativity in a series of six papers in 1926 [13-18]. In its most general form, the time-dependent Schrödinger equation describes the time evolution of closed quantum physical systems as

$$
\imath \hbar \frac{\partial}{\partial t} \Psi(\mathbf{r}, t)=\hat{H} \Psi(\mathbf{r}, t)
$$


where $l$ is the imaginary unit, $\hbar$ is the reduced Planck constant, the symbol $\frac{\partial}{\partial t}$ indicates a partial derivative with respect to time $t, \Psi$ is the wave function of the quantum system, $\mathbf{r}$ and $t$ are the position vector and time respectively, and $\hat{H}$ is the Hamiltonian operator characterizing the total energy of the quantum system. Wave mechanics, as proposed by Schrödinger [19], was the second formulation of quantum theory, the first being matrix mechanics due to Heisenberg. The relation between the two formulations of wave mechanics and matrix mechanics was understood by Schrödinger immediately as this quotation from one of his 1926 papers shows

To each function of the position- and momentum- coordinates [in wave mechanics] there may be related a matrix in such a manner, that these matrices, in every case satisfy the formal calculation rules of Born and Heisenberg. [...] The solution of the natural boundary-value problem of this differential equation [in wave mechanics] is completely equivalent to the solution of Heisenberg's algebraic problem. [19. p. 46]

The work was indeed received with great acclaim. Max Planck described it as

epoch-making work [1, §6]

Einstein wrote:

the idea of your work springs from true genius [1, §6]

Then, ten days later Einstein wrote again:

I am convinced that you have made a decisive advance with your formulation of the quantum condition $[\ldots][1, \S 6]$

Paul Ehrenfest wrote:

I am simply fascinated by your [wave equation] theory and the wonderful new viewpoints that it brings. Every day for the past two weeks our little group has been standing for hours at a time in front of the blackboard in order to train itself in all the splendid ramifications. [1, §6]

The author of Schrödinger's obituary in The Times wrote

The introduction of wave mechanics stands

[...] as Schrödinger's monument and a worthy one. [20]

Schrödinger accepted an invitation to lecture at the University of Wisconsin, Madison, leaving in December 1926 to give his lectures in January and February 1927. Before he left he was told he was the leading candidate for Planck's chair in Berlin. After giving a brilliant series of lectures in Madison he was offered a permanent professorship there but:

He was not at all tempted by an American position, and he declined on the basis of a possible commitment to Berlin. [1, §7]

The list of candidates to succeed Planck in the chair of theoretical physics at Berlin was impressive. Arnold Sommerfeld was ranked in first place, followed by Schrödinger, with Max Born as the third choice. When Sommerfeld decided not to leave Munich, the offer was made to Schrödinger. He went to Berlin, taking up the post on October 1, 1927 and there he became a colleague of Einstein's.

Although he was a Catholic, Schrödinger decided in 1933 that he could not live in a country in which persecution of Jews had become a national policy. Alexander Lindemann, the head of physics at Oxford University, visited Germany in the spring of 1933 to try to arrange positions in England for some young Jewish scientists from Germany. He spoke to Schrödinger about posts for one of his assistants and was surprised to discover that Schrödinger himself was interested in leaving Germany. Schrödinger asked for a colleague, Arthur March, to be offered a post as his assistant.

To understand Schrödinger's request for March we must digress a little and comment on Schrödinger's liking for women. His relations with his wife had never been good and he had had many lovers with his wife's knowledge. Anny had her own lover for many years, Schrödinger's friend Weyl. Schrödinger's request for March to be his assistant was because, at that time, he was in love with Arthur March's wife Hilde.

Many of the scientists who had left Germany spent the summer of 1933 in the South Tyrol. Here Hilde became pregnant with Schrödinger's child. On November 4, 1933 Schrödinger, his wife and Hilde March arrived in Oxford. Schrödinger had been elected a fellow of Magdalen College. Soon after they arrived in Oxford, Schrödinger heard that, for his work on wave mechanics, he had been awarded the Nobel prize.

In the spring of 1934, Schrödinger was invited to lecture at Princeton and while there he was made an offer of a permanent position. On his return to Oxford he negotiated about salary and pension conditions at Princeton but in the end he did not accept. It is thought that the fact that he wished to live at Princeton with Anny and Hilde both sharing the upbringing of his child was not found acceptable. The fact that Schrödinger openly had two wives, even if one of them was married to another 
man, did not go down too well in Oxford either, but his daughter Ruth Georgie Erica was born there on May 30, 1934.

In 1935, Schrödinger published a three-part essay on The Present Situation in Quantum Mechanics [21-23] in which his famous Schrödinger's cat paradox appears. This was a thought experiment where a cat in a closed box either lived or died according to whether a quantum event occurred. The paradox was that both universes, one with a dead cat and one with a live one, seemed to exist in parallel until an observer opened the box.

In 1936, Schrödinger was offered the chair of physics at the University of Edinburgh in Scotland. He may have accepted that post but for a long delay in obtaining a work permit from the Home Office. While he was waiting he received an offer from the University of Graz and he went to Austria and spent the years 1936-1938 in Graz. Born was then offered the Edinburgh post which he quickly accepted.

However the advancing Nazi threat caught up with Schrödinger again in Austria. After the Anschluss the Germans occupied Graz and renamed the university Adolf Hitler University. Schrödinger wrote a letter to the University Senate, on the advice on the new Nazi rector, saying:

I had misjudged up to the last the true will and the true destiny of my country. I make this confession willingly and joyfully. [1, §9]

It was a letter he was to regret for the rest of his life. He explained the reason to Einstein in a letter written about a year later:

I wanted to remain free - and could not do so without great duplicity. [1, §9]

The Nazis could not forget the insult he had caused them when he fled from Berlin in 1933 and on August 26, 1938 he was dismissed from his post for "political unreliability". He went to consult an official in Vienna who told him that he must get a job in industry and that he would not be allowed to go to a foreign country. He fled quickly with Anny, this time to Rome from where he wrote to Éamon de Valera as President of the League of Nations. De Valera offered to arrange a job for him in Dublin in the new Institute for Advanced Studies he was trying to set up. From Rome, Schrödinger went back to Oxford, and there he received an offer of a one year visiting professorship at the University of Gent.

After his time in Gent, Schrödinger went to Dublin in the autumn of 1939. There he studied electromagnetic theory and relativity and began to publish on a unified field theory. His first paper on this topic was written in 1943. In 1946, he renewed his correspondence with Einstein on this topic. In January 1947, he believed he had made a major breakthrough:

Schrödinger was so entranced by his new theory that he threw caution to the winds, abandoned any pretence of critical analysis, and even though his new theory was scarcely hatched, he presented it to the Academy and to the Irish press as an epoch-making advance. [1, §11]

The Irish Times carried an interview with Schrödinger the next day in which he said:

This is the generalisation. Now the Einstein Theory becomes simply a special case [...] I believe I am right, I shall look an awful fool if I am wrong. [1, §11]

Einstein, however, realised immediately that there was nothing of merit in Schrödinger's "new theory".

[Schrödinger] was even thinking of the possibility of receiving a second Nobel prize. In any case, the entire episode reveals a lapse in judgment, and when he actually read Einstein's comment, he was devastated. [1, §11]

Einstein wrote immediately saying that he was breaking off their correspondence on unified field theory. Unified field theory was, however, not the only topic to interest Schrödinger during his time at the Institute for Advanced Study in Dublin. His study of Greek science and philosophy is summarised in Nature and the Greeks (1954), which he wrote while in Dublin. Another important book written during this period was What is Life? (1944) [24] which led to progress in biology.

On the personal side Schrödinger had two further daughters while in Dublin, to two different Irish women. He remained in Dublin until he retired in 1956 when he returned to Vienna and wrote his last book My View of the World (1961) expressing his own metaphysical outlook.

During his last few years Schrödinger remained interested in mathematical physics and continued to work on general relativity, unified field theory and meson physics.

\section{References}

[1] Moore WJ. Schrödinger: Life and Thought. Canto Classics, Cambridge: Cambridge University Press, 2015.

[2] Schrödinger E. Über die Leitung der Elektrizität auf der Oberfläche von Isolatoren an feuchter Luft. Sitzungsberichte der kaiserlichen Akademie 
der Wissenschaften in Wien. Mathematischnaturwissenschaftliche Klasse, Abteilung $2 a$ 1910; 119: 1215-1222.

[3] Schrödinger E. Theorie der Pigmente von größter Leuchtkraft. Annalen der Physik 1920; 367(15): 603-622. doi : 10.1002/andp. 19203671504

[4] Schrödinger E. Grundlinien einer Theorie der Farbenmetrik im Tagessehen: I. Mitteilung. Annalen der Physik 1920; 4(63): 397-426. doi: 10.1002/ andp.19203682102

[5] Schrödinger E. Grundlinien einer Theorie der Farbenmetrik im Tagessehen: II. Mitteilung. Annalen der Physik 1920; 4(63): 427-456. doi : 10.1002/ andp.19203682103

[6] Schrödinger E. Grundlinien einer Theorie der Farbenmetrik im Tagessehen: III. Mitteilung. Annalen der Physik 1920; 4(63): 481-520. doi : 10.1002/ andp.19203682202

[7] Schrödinger E. Farbenmetrik. Zeitschrift für Physik 1920; 1(5): 459-466. doi : 10.1007/bf01332674

[8] Schrödinger E. Über das Verhältnis der Vierfarbenzur Dreifarbentheorie. Sitzungsberichte der kaiserlichen Akademie der Wissenschaften in Wien. Mathematisch-naturwissenschaftliche Klasse, Abteilung $2 a$ 1925; 134: 471-490.

[9] Schrödinger E. On the relationship of four-color theory to three-color theory, with Commentary by Qasim Zaidi. Color Research E Application 1994; 19(1): 37-47. doi: 10.1111/j .1520-6378. 1994.tb00059.x

[10] Schrödinger E. Über Farbenmessung. Physikalische Zeitschrift 1925; 26: 349-352.

[11] Schrödinger E. Über die subjektiven Sternfarben und die Qualität der Dämmerungsempfindung. Naturwissenschaften 1925; 13(18): 373-376. doi : $10.1007 / \mathrm{bf01559096}$

[12] Schrödinger E. Die geometrische Lösung von Farbenmischungsaufgaben. Naturwissenschaften 1926; 14(8): 146-147. doi : 10.1007/bf01507301

[13] Schrödinger E. Quantisierung als Eigenwertproblem: Erste Mitteilung. Annalen der Physik 1926; 4(79): 361-376. doi:10.1002/andp. 19263840404
[14] Schrödinger E. Quantisierung als Eigenwertproblem: Zweite Mitteilung. Annalen der Physik 1926; 4(79): 489-527. doi:10.1002/andp. 19263840602

[15] Schrödinger E. Über das Verhältnis der HeisenbergBorn-Jordanschen Quantenmechanik zu der meinem. Annalen der Physik 1926; 4(79): 734-756. doi:10.1002/andp.19263840804

[16] Schrödinger E. Quantisierung als Eigenwertproblem: Dritte Mitteilung. Annalen der Physik 1926; 4(80): 437-490. doi:10.1002/andp. 19263851302

[17] Schrödinger E. Quantisierung als Eigenwertproblem: Vierte Mitteilung. Annalen der Physik 1926; 4(81): 109-139. doi:10.1002/andp. 19263861802

[18] Schrödinger E. Der stetige Übergang von der Mikrozur Makromechanik. Naturwissenschaften 1926; 14(28): 664-666. doi : 10.1007/bf01507634

[19] Schrödinger E. Collected Papers on Wave Mechanics. London: Blackie \& Son, 1928. https://archive.org/details/in.ernet. dli.2015.211600

[20] Professor Erwin Schrödinger: Physicist and Nobel Prize Winner. The Times, 1961. http://www-history.mcs.stand.ac.uk/Obits/Schrodinger.html

[21] Schrödinger E. Die gegenwärtige Situation in der Quantenmechanik. I. Naturwissenschaften 1935; 23(48): 807-812. doi : 10.1007/bf01491891

[22] Schrödinger E. Die gegenwärtige Situation in der Quantenmechanik. II. Naturwissenschaften 1935; 23(49): 823-828. doi : 10.1007/bf01491914

[23] Schrödinger E. Die gegenwärtige Situation in der Quantenmechanik. III. Naturwissenschaften 1935; 23(50): 844-849. doi : 10.1007/bf01491987

[24] Schrödinger E. What is Life? The Physical Aspect of the Living Cell $\mathcal{G}$ Mind and Matter. Cambridge: Cambridge University Press, 1977. https:// archive.org/details/WhatIsLife_201708 